\title{
Parent-Child Relationship: Peculiarities and Outcome
}

\author{
Leonid M. Popov ${ }^{1} \&$ Ruth A. Ilesanmi ${ }^{1}$ \\ ${ }^{1 .}$ Kazan (Volga region) Federal University, Kazan, Russia \\ Correspondence: Leonid M. Popov, Kazan (Volga region) Federal University, Kremlyovskaya Street 18, \\ Kazan, 420008, Russia. E-mail: ruthilesanmi01@gmail.com
}

Received: January 19, 2014 Accepted: February 22, 2015 Online Published: March 30, 2015

doi:10.5539/res.v7n5p253 URL: http://dx.doi.org/10.5539/res.v7n5p253

\begin{abstract}
The relationship between parents and their children can be regarded as the most important relationship an individual can experience. This paper, examines theoretical and empirical literature on parent-child relationships by analyzing recent accomplishments on this issue. It turns first to the question of which behaviors in children are associated with those of their parents? This paper also reviews researches on: factors that influence parent-child relationship from an integrative contextual-empirical perspective. It is indeed true that parents are usually the ones who spend the most time with young children over extended periods of time; therefore this paper seek answers to the question of whether parents really have influence(s)on their children, to what extent and the importance of these influences. The results of this paper showed that temperament, antisocial and externalizing behaviors (e.g. substance abuse) were the most reported behavioral characteristics between parents and their children.
\end{abstract}

Keywords: parent-child relationship, attachment theory, parent-adult child relationship, parent and child behavior

\section{Introduction}

Parent-child relationships constitute a very special type of relationship in which every human is personally involved. According to Troll \& Fingerman (1996), parent-child relationship is specific in nature and differs from all other kinds of relationships (such as partners, family and friends) because of its degree of intimacy. Researchers who have studied parent-child relationships focused on different aspects. Some characterized their study based on how parent-child relationship influences children's decision making and communication (Field et al., 2007); Effects of parent-child relationship in the development of children's emotional functioning and regulation (Boutelle et al., 2009); With the advent of extensive research in genetics, some researchers further explored the genetic nature of parents and how it influences the characteristics that children exhibit (Maccoby, 2000); While a large number of studies focus on issues like parental attachment (Antonucci et al., 2004; Bohlin et al., 2000). Parents are not the only source of influence on children; as children grow, they are more subject to the influence of peers, mass media, and other external factors outside the family. In this paper we focus on parental influence on children. It is important to note that the relationship that exists between parents and their children portray the type of families they come from.

\section{Theoretical Framework}

\subsection{The Domain Perspective: Attachment Theory}

The study of parent-child relationship had been based on attachment theory and had given remarkable results. Attachment theory as it relates to children emphasizes the importance of caring relationships for normal development of the child; it also suggests that a good nurturing relationship between parent and child shapes future social, cognitive, and emotional development of that child (Antonucci et al., 2004). John Bowlby in 1973 formulated attachment theory by drawing concepts from biology and psychoanalysis. According to this theory, children develop internal representations of relationships as a result of interactions with their primary caregivers (e.g. parents), which they subsequently use in maintaining other relationships. Attachment theory also presumes that parent-child relationship has long term consequences for shaping a child's psychological functioning.

During infancy, parent-child relationship is characterized by high levels of bonding of children with their parents (especially mothers), due to strong emotional and physical ties between a child and his or her parents. The loss of the attachment figure is accompanied by anxiety and grief, which can lead to problems in the child's social and 
emotional development (Varga, 2011). Strong attachment ties between children and their parents are a necessary condition for good mental health of the future adult (Bowlby, 1973). Attachment of an infant to a parent is believed to be developed through consistent responsiveness by a parent to the child's needs, resulting in internal working models of attachment and caring relationships (Boutelle et al., 2009).

\subsection{Behavioral Characteristics between Parents and Children}

Studies continue to vary considerably in respect to the degree of correlations between parent and child behavior. It has been shown that a given parent behavior may have different effects on different children, depending on factors such as age, sex, and temperament. Behaviors such as: antisocial and externalizing, temperament, and parent and child negative affectivity are reviewed in this paper.

\subsubsection{Focus on Antisocial and Externalizing Behaviors}

Research on parenting characteristics (e.g. disciplinary practices and monitoring) and children's antisocial behavior showed substantial correlations. That is, negative parenting behavior influences parent-child relationship which leads to reduction in child supervision, more punitive discipline and less child involvement; these can further lead to antisocial behavior in children. Many of the studies evaluating relationship between children and parents have evaluated behaviors that could be considered externalizing, such as alcohol and drug use (Brook et al., 2002; Windle, 2000). Parental permissiveness was linked to child self-regulation (Patock-Peckham et al., 2001), while aggressive behavior in parents (that is, corporal punishment) to poor emotional and behavioral adjustment in children (Aucoin et al., 2006; Johnston et al., 1998). It is important to note that in reciprocal effect models, not only do parents affect child behavior and parent-child interactions, but child functioning also serves to elicit parental reactions.

\subsubsection{Focus on Temperament}

Temperament which refers to an individual's behavioral style as he or she relates to other persons and to the inanimate environment has been linked to parent-child relationship. It develops early in life (Rettew et al., 2010), undergoes a process of modification throughout life span (Nigg \& Hinshaw, 1998), and is partially rooted in a person's genetic makeup (Lemery et al., 2002; Olson et al., 2000). Various studies on temperament have shown relations between temperament and genetics. Researchers have identified children with different temperaments, and studied how they differ in the way they interact with their parents and in the impact parental inputs have on them. For example, Schmeck \& Poustka (2001), have shown that children's temperamental characteristics initiate bi-directional processes that occur between them and their parents. According to Brody (1998), a given parental practice can have different effects on children with different temperaments. Parental firmness and restrictiveness are important factors in preventing the development of externalizing behavior in resistive and difficult children, than is the case of children with easier temperaments (Bosmans et al., 2006; Rettew et al., 2010).

\subsubsection{Parent and Child Negative Affectivity}

Researchers have examined the effects of parent negative affectivity especially depression and hostility, as variations in relationship between parents and children. Depressed and hostile parents have been found to be less involved with and affectionate toward their children, feel more guilt and resentment, and exhibit poor communication skills with their children (Barnard \& McKeganey, 2004). Higher levels of parent negative affectivity were also found to be related to higher levels of negativity in adolescent children (Galen \& Underwood, 1997); for example, substance abuse such as marijuana (Riggs et al., 2009), depressive symptoms (Boutelle et al., 2009; Difilippo \& Overholser, 2002), Suicidal thoughts or attempts (Laird et al., 2003). Furthermore, some researchers have also shown links between parent-child relationships and psychological outcomes in children, such as conduct problems (Galen \& Underwood, 1997; Schmeck \& Poustka, 2001), anxiety and antisocial personality disorder in adulthood. Some studies reported associations between parental substance use and other child outcomes such as physical, cognitive, academic, and social-emotional adjustment (Barnard \& McKeganey, 2004; Day et al., 2006; Orlando et al., 2005). For example, marijuana is regarded as the most commonly illicit drug with high international consumption (Smart \& Ogborne, 2000). Indiscriminate use of marijuana persists into adulthood (from childhood) due to the well-established link between parents' substance use and negative outcomes in their children. This is of public health concern because of the negative psychosocial consequences (such as mental illness), as well as increased susceptibility to chronic diseases (such as cancers), that occurs later in life as a result of its consumption (Chacko et al., 2006). 


\subsection{What are the Topical Concerns of Family Structure, Parenting Style and Divorce on Parent-Child Relationships?}

\subsubsection{The Challenge from Family Structure}

According to social psychologists, a family can be defined as a fundamental social group in the society typically consisting of one or two parents and their children. In psychology, the concept of family is examined based on the essence of family and the dynamics of family interactions. In most cultures, early socialization occurred from the context of families, more specifically, parent-child interactions (Grusec, 2011). Each subsystem of the family is important in understanding parent-child relationship. In general, there are two major types of family: Nuclear (consists of a mother, father, and their children), and Extended family (consists of more relatives, includes parents, children, cousins, aunts, uncles, grandparents, foster children, etc.). Other important forms of family includes: single parent and step families.

Orlov (1996), described two types of family in relation to parent-child relationship. a) The person-centered family; b) The socio-centered family. Person-centered families are characterized by high levels of attention paid to the personality of the child and his or her inner world, respect for his or her needs and values, and unconditional acceptance of his or her individuality. In contrast, socio-centered families are characterized by more likelihood to neglect the child's needs and values, more ambivalent relationships and acceptance of the child only if he or she shares the parents' point of view (Orlov, 1996). The socio-centered family is most importantly concerned with the social roles of each child in the family, while in the person-centered family; every child is treated as an individual. According to Fincham (1998), the quality of marital relationship also has a direct influence on the quality of parent-child relationship; that is, strong marital bond leads to strong parent-child relationship.

Due to the various types of assisted reproduction, questions are arising from different forms of gestational relationships between parents and children. For example, selected set of characteristics (genetics) that were obtained from both biological and adoptive parents showed more similarities between adopted children and their biological parents than to their adoptive parents (Golombok et al., 2006; Maccoby, 2000). In the case of gamete donation, it was reported that fathers were more distant from a non-genetic child (Golombok et al., 2005). Studies of step-parent families point to difficult relationships between step-parents and step-children (Hetherington \& Stanley-Hagan, 2002); that is, parents in stepfamilies that included both step-children and genetically related children were reported to be less affectionate towards, and less supportive of their stepchildren than their own biological children. It is important to note that family structure does not only act as a strong determining factor of the type of relationship that exists between parents and their children, but it also depicts the strength of the relationship.

A fundamental aspect of family structure that cannot be left behind when discussing parent-child relationship is communication. Communication is the engine of social relationships and a necessity for all relationships. It involves listening, availability, understanding, mutual respect and emotion. In essence, to communicate means to know how to give and how to receive. Communication plays a vital role when it comes to parent-child relationship; it establishes and maintains relationship between parents and children, it makes interaction between parents and children strong and effective, and it contributes significantly to creating understanding and mutual acceptance between parents and children. This means that the more parents communicate with their children, the more children improve their communication abilities (that is good relations with people around them). Ngai et al. (2013), stated that communication is very important in parent-child interaction, especially if parents want to find better ways of transmitting important life values to their children. Hence, good parent-child communication filled with trust and respect can enhance children's autonomy and provide adequate support for them to accomplish the developmental tasks during adolescence (Lai \& McBride-Chang, 2001). In an experiment conducted by Ngai et al. (2013), results revealed that parent-child communication contributes more to children development than parental supervision and parental care. The time spent by parents with the child has an essential and well-defined role in the relationship between parent and child. Patricia-Luciana Runcan (2011), studied the factor-time spent with the child, and found that the time spent with the child influences communication between parents and children in a positive way, especially when the parent allocates sufficient time to the child.

\subsubsection{The Challenge from Parenting Style}

Every family is a unique system with its own rules and traditions. When a child is born, he or she becomes a part of this system and gradually adapts to it. In most societies, parents are the ones assigned primary responsibility to train children in desirable directions, by supervising, teaching, and disciplining them as they grow up. Children learn moral values through the process of socialization, much of which involves parenting. Parenting is 
a bidirectional process that involves a complex interplay between evolutionary predispositions, genetic and socio-cultural factors (Grusec, 2011). Fincham (1998), suggested that marital relationship may be the most influential relationship because it sets the tone for all other relationships in the home by creating an environment that facilitates effective parenting. Some studies also suggest that parenting practices have a reciprocal influence on child behavior (Lau et al., 2006). For example, parental supervision was found to be the strongest predictor of behavioral adjustment in children, while parental care, the strongest predictor of resilience, that is, capacity to adapt to change and stressful events in a healthy way (Ngai et al., 2013). Some studies have indicated that children may vary in their susceptibility to parental rearing. More specifically, Belsky (2005), hypothesized that not all children are similarly susceptible to the effects of parenting; this is as a result of evolutionary reasons such as age and sex.

One aspect of parenting style that has emerged in recent studies relating to children's well-being centers around the ability of some parents to develop reciprocal form of interaction with their children such as: shared positive affect and mutual responsivity (Maccoby, 2000). Parenting behaviors are majorly shaped by social norms and expectations (such as community, cultural values and the associated social and legal policies in which they are embedded). According to Kochanska et al. (2007), disciplinary strategies used by mothers did not predict internalization of behavioral prohibitions, but affectively warm mother-child relationships did. Although Ngai \& Cheung (2009), reported that parents who behave with high nurturance and have more democratic parent-child interaction are more likely to raise children who show higher levels of mental health, identity achievement, behavioral adjustment, resilience, and academic performance.

Parenting styles are also known to be associated with anxiety in children (Field et al., 2007); although little is known about the mechanism through which parenting has this effect. In an experiment conducted by Field et al. (2007), it was observed that parenting practices influence how children react to negative information. Evidence has shown that high quality parenting can facilitate children's psychosocial adjustment to economic hardship during their transition from childhood to adulthood (Crosnoe et al., 2002; Orthner et al., 2004). Bugental \& Johnston (2000), suggest that parents' experiences with their own children may have a greater impact at the level of specific cognitions (for example, sense of parenting efficacy in managing a particular child), rather than global parental beliefs. Recent evidence now suggest that parenting styles characterized by lack of warmth and acceptance, overcontrol and overprotection, and high levels of criticism, may be risk factors for negative behavior in children (Wood et al., 2003).

\subsubsection{The Question of Divorce}

Divorce which is the legal dissolution of marriage or marital bond between couples has been shown to have some negative effects on parent-child relationships; this is because a large number of children have good relationships with both parents (in terms of contact and support), but this is less seen when parents are divorced (Albertini \& Garriga, 2011). Three main causes of poor outcome of parent-child relationship due to divorce include: 1) Most children of divorced parents cannot see their parents at the same time (Albertini \& Garriga, 2011; Swiss \& Bourdais, 2009); this leads to a deterioration of the relationship with one parent while at the same time the relationship with the other parent improves. 2) Majority of parents experience psychological problems after divorce which reduces the attention they give to their children (Albertini \& Garriga, 2011). 3) Some children blame their parents for the divorce which invariably leads to more detached attitude toward both parents.

Geuzaine et al. (2000), reported that there are negative long-term effects of parental separation and divorce on relationships between parents and children (these negative effects are especially seen in children). These include: low self esteem, emotional and behavioral problems, poor school achievement, and juvenile delinquency. Studies on the impact of parents' divorce on parent-child relationships that have used samples of young children show negative effect of parental divorce on relationship outcome with fathers and show no effect of divorce on relationship outcome with custodial mothers. One explanation for this discrepancy is that the effects of divorce on relationship between parents and children might be less among younger children who experienced their parents' divorce in recent historical period when single mothers were subject to fewer stigmas. This suggests that children may choose between parents after divorce. In general, divorce increases inequality in the relationships that children have with their father and mother (Albertini \& Garriga, 2011; Bohlin et al., 2000; Geuzaine et al., 2000; Swiss \& Bourdais, 2009). 


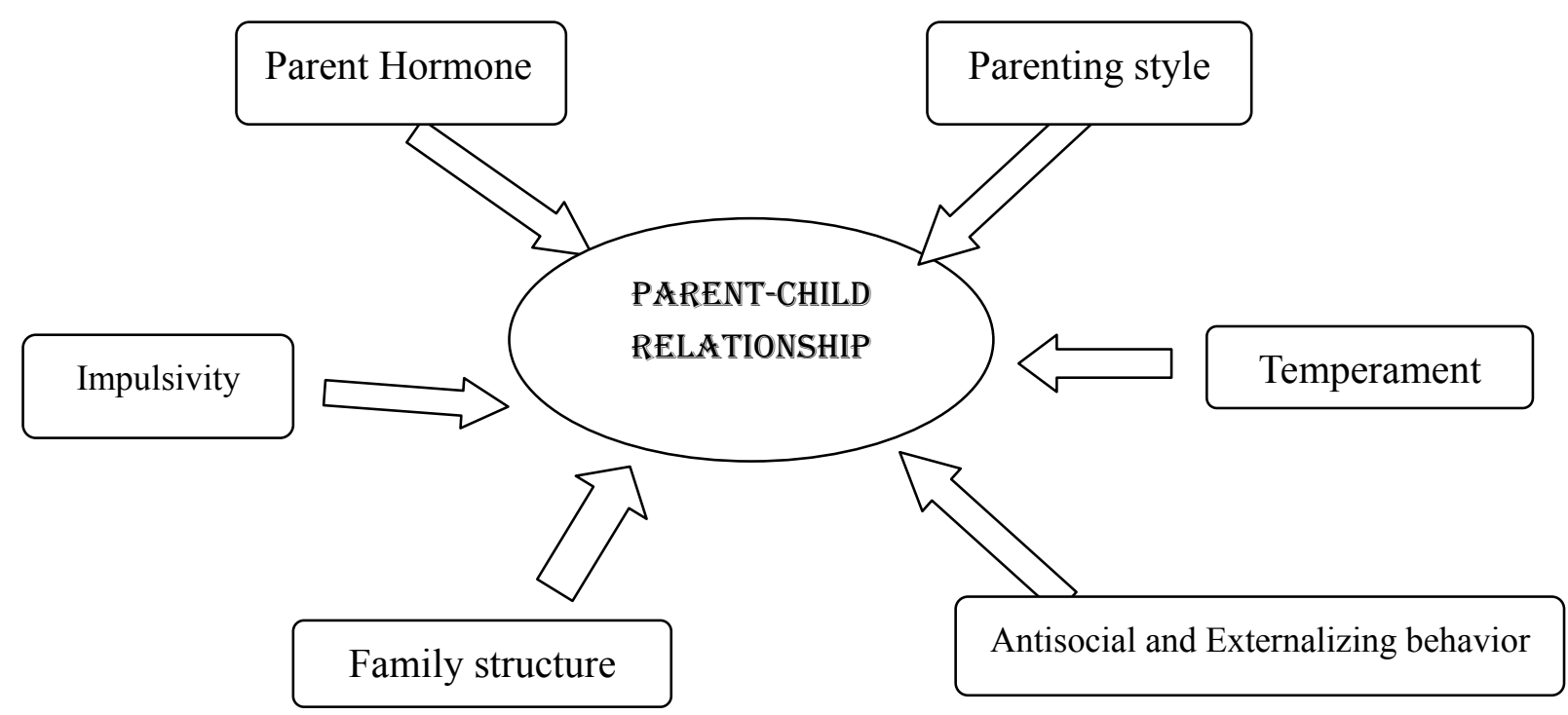

Figure 1. Factors that influence parent-child relationship

\subsection{Parent-Adult Child Relationship: An Important Differential in Parent-Child Relations}

We found that there was no single construct known to represent all sections of parent-adult child relationship; but some researchers have investigated variables intended to assess them. They include: Exchange of emotional support and advice (Bonsang, 2009); Feelings of attachment and closeness (Haberkern \& Szydlik, 2010); and scale measures of relationship quality (Grundy \& Henretta, 2006; Lowenstein et al., 2007).

It has been shown that closer relationship tend to exist between adult children and their parents when they have children (Dykstra \& Fokkema, 2011); that is, parents will provide more support to adult children who have children, especially if their grandchildren are still very young (Hoff, 2007).

According to Lye (1996), parent-adult child relationship can be differentiated based on four factors: 1) Contact and proximity, 2) Relationship quality, 3) Exchanges of assistance, and 4) Norms and expectation. Findings concerning racial and ethnic differences in the relationship that exists between parents and their adult children have also been inconsistent; this can be traced to lack of nationally representative data. In some studies black adult children were reported to have closer relationships with their mothers than do whites (Szinovacz \& Davey, 2013); although Teresa (2009), reported that black mothers receive less emotional support from their adult children than do whites, while Hispanics exhibit lower quality of parent-adult child relationship. In general, adult daughters were reported to have more closer relationship with their parents than do adult sons, due to frequent contact with parents (Carpenter, 2001); but adult children (whether male or female) have less contact with their fathers than with their mothers (Ahrons \& Tanner, 2003).

Divorce was also reported to weaken parent-adult child relations. According to Fingerman and Birditt (2011), adult children and their parents display emotionally satisfying relationships, but exchanges of practical and financial assistance are uncommon when parents are divorced. Divorced fathers are less likely to have a closer relationship with their adult children and be less involved in exchanges of assistance with their children (Ahrons \& Tanner, 2003). It is important to note that as time passes, both adult children and their parents change in the attitudes and in the manner they approach each other.

\subsection{Outcome of Parent-Child Relationship}

Relationship between parents and their children have been reported to yield certain results. Among them includes:

\subsubsection{Socio-Emotional Effect}

As earlier discussed, the result of poor parent-child relationship has been reported to be closely associated with aggressive behavior and delinquency; these behaviors are among the most reported findings in the literature. It has been demonstrated that several dimensions of parent-child relationships are independently associated with this disturbance (Fletcher et al., 2004). As regards socio-emotional outcome, children have been reported to 
show closer and more positive relationships with their parents (Phillips \& Lowenstein, 2011). However, only the children that manage to have a good relationship with their parents will extend social and emotional relationships normally with their peers. Every child need the presence of his/her parent to a certain degree, although time spent with parents means a lot more to smaller children than it does to more grown-up children. Just as each parent want to relate better with his/her child, every child wants to spend time with his/her parent in different ways. Studies have shown that one of children's biggest desires is to play with those that gave them life. During workdays majority of parents do not have time and patience to play with their children; this is majorly due to career-related occupation. Even when they do communicate, discussions between children and parents are limited only to school problems and do not extend to the children's feelings or wishes. It is important to note that lack of involvement in children's lives can lead to weaker and more superficial parent-child interaction, thus generating complex problems for the child's future.

\subsubsection{The Role of Genetics}

Today, there has been enormous research about the genetic nature of parents and children as it relates to the character that children develop. In twin and adoption studies, interactions between parent and child are thought to imply that genetics (either the child's own or the genes shared with parents) have consequential effects on parent-child relations. There is also clear evidence that children's genetic makeup affects their behavioral characteristics, and also influences the way they are treated by their parents (Golombok et al., 2006; Maccoby, 2000). Some studies that explored children's relationship with their parents, with emphasis on relationship as a characteristic of children's world reported a moderate heritability (Dunn et al., 2000), and increasing genetic influence during adolescence (Shiner \& Caspi, 2003). Reports from behavior geneticists have shown that familial circumstances such as parental illness or health, economic prosperity or adversity, good or poor parenting, all have a powerful influence on the relationship between parents and their children. Quantitative geneticists reported that parent-child relationship could stem from genetic predispositions shared by parents and children, and is directly transmitted from one generation to the next. But according to Dunn et al. (2000), the absence of a genetic and/or gestational link between parents and their child does not have a negative impact on parent-child relationships.

\subsubsection{Cognitive Effect}

The fact that parents are the most important influence on children's development cannot be underestimated. Cognitive theorists have proposed that parent-child relationship is an essential environmental context in which structuring of the child's emerging cognitive abilities take place. According to Bugental and Johnston (2000), reciprocal interactions between parents and children provide the collaborative basis for the creation of shared knowledge. Authoritative parenting was reported to be associated with higher school achievement than the other parenting styles (Glasgow et al., 1997); and secure parental attachment was linked with academic achievement in secondary school (Feldman et al., 1998). Parent's response has been shown to be a function of children's initiative; this means that parents who pay special attention to their children can be expected to provide an optimal environment for the child to learn, which can further be strengthened by the child's own motivation. Adoption studies have also shown that there are correlations between adopted children's intelligent quotient (IQ) and those of their biological parents (Maccoby, 2000).

\subsubsection{Health/Medical}

Parent-child relationships are important and have been linked to the health and social well-being of children (Habib et al., 2010). A number of studies in the past have been able to show that poor quality relationships between parents and their children (especially in parent-adult child relationship) create increased susceptibility to a range of health problems, such as cardiovascular and musculoskeletal disorders (Dykstra \& Fokkema, 2011). Poor parent-child relationships in adolescence are associated with greater burden of self-reported ill health that are attributable to the changes in the neurohumoral response (Stewart-Brown et al., 2005), and could be a remediable risk factor for poor health in children as they grow. Researchers in time past have also shown that children from divorced families experience poorer mental health than those from intact families (Ledoux et al., 2002); there were more reports of alcohol, antisocial behaviors, and other drug use as they grow up (Griffin et al., 2000), or at even more earlier age.

Recently, hormones have also become central in explaining parent-child relationship (Booth et al., 2006; Dorius et al., 2011), and hormone-related adolescent problem moderated by parent-child closeness (Booth et al., 2003). Today, only few researchers study hormones in conjunction with parent-child relationship. An important aspect of hormonal link with parent-child relationship is parent's hormone, especially father's testosterone. Scientific researches on men have shown a link between concentrations of testosterone and behaviors that have effects on 
the relationship that exists between parents and their children (Dorius et al., 2011). Notably is the fact that high testosterone is often tempered by social context; as a result of this, high testosterone in fathers remains a potential threat to parent-child relationship, and can lead to poor relationship between fathers and their children. It was further reported that when father's marital satisfaction is low, mothers with high testosterone exhibit poorer relationship with their children; and when fathers report low levels of intimacy with their children, high testosterone women exhibit poorer relationship with their children (Dorius et al., 2011).

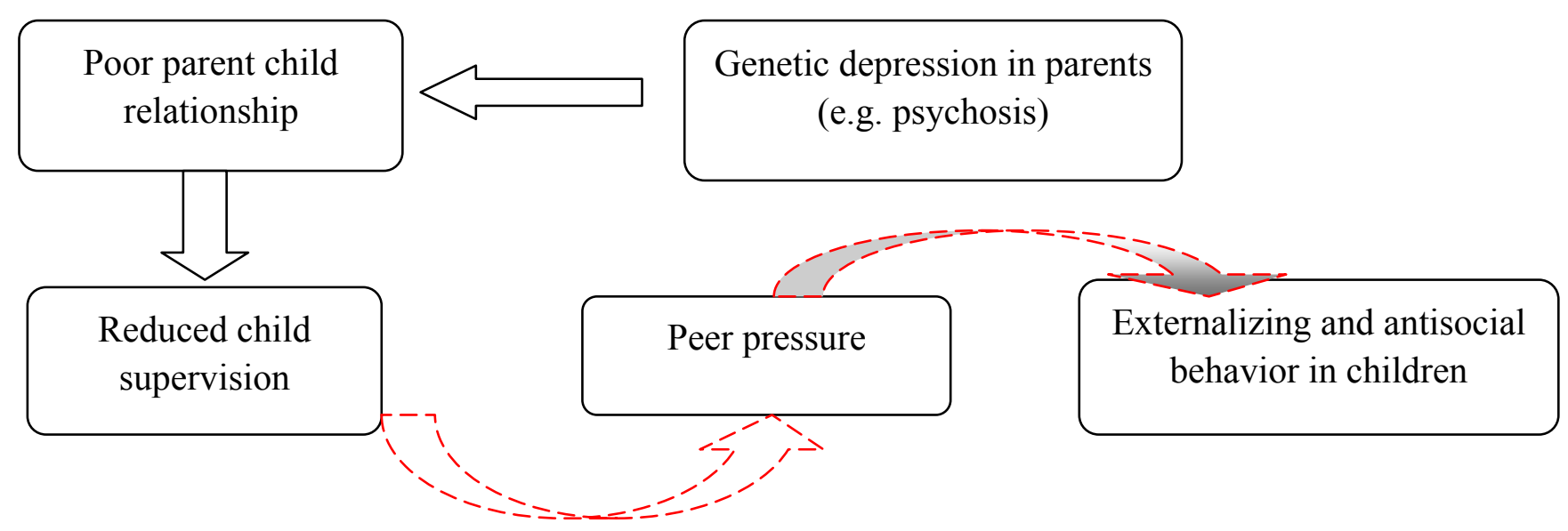

Figure 2. Outcome of poor parent-child relationship

\section{Conclusion}

More recently in family context, views of parenting and parent-child relationship have expanded to include parents as active managers of the child's social environment. A healthy interaction between parents and their children represents a good family environment, an affective dimension of a positive nature, and the presence of affective support. This interaction positively influences the child's state and behavior, and plays a great role in the child's normal, physical and mental development. Conflict in the family will hinder this kind of interaction.

Although some studies show negative effects of divorce on father-child relationships, it is unclear if these effects are additive from the children's point of view. The question of whether children who experience a decline in relationship with their father also experience a decline in relationship with their mother calls for further research. Good relationship between parents and their children have been shown to enhance general well-being (in children) and result in better social life, protect against emotional distress and suicide, and prevents children from engaging in risky unhealthy behaviors. Supportive parent-child relationships override the dispositions of children prone to noncompliance behaviors.

Research linking parent's hormone to relationship between parents and their children is limited; more study is therefore required to understand the extent to which children might be at risk of having poor relationships with their high testosterone fathers. Poor parent-child relationships were reported to contribute to the development of internalizing symptoms such as depression, low self-esteem, and body image difficulties in children, and it is also possible that children with these symptoms may engage less with their parents. Increased self-esteem (both in male and female child) is as a result of good parent-child connectedness and can further lead to an increase in body satisfaction in female children. These results emphasize the importance of good parent-child relationship in combating such negativities as low self esteem. Based on the results of various researches as compiled in this review, we conclude that parents can and do influence their children; and that parents' genetic make-up, hormone, behavior and parenting style influences the way they treat their children.

\section{Future Direction}

1) Several studies reviewed in this paper have clearly shown that treatment can change a parent's behavior towards a child in specified ways, which in turn changes children's behavior. Therefore, in order to enhance good parent-child relationship, poor parenting practices should be changed. This can only occur through the introduction of longitudinal parent-training programs.

2) Reduction of parent-to-child coercive behavior through the intervention of parent training was also reported to elicit declining levels of antisocial behavior in aggressive children. 


\section{Acknowledgements}

This review was carried out in accordance to the Russian Government Program on Competitive growth of Kazan Federal University.

\section{References}

Ahrons, C. R., \& Tanner, J. L. (2003). Adult Children and Their Fathers: Relationship Changes 20 years after parental divorce. Family Relations, 52, 340-351. http://dx.doi.org/10.1111/j.1741-3729.2003.00340.x

Albertini, M., \& Garriga, A. (2011). The effect of divorce on parent-child contacts: Evidence on two declining effect hypotheses. European Societies, 13, 257-278. http://dx.doi.org/10.1080/14616696.2010.483002

Antonucci, T. C., Akiyama, H., \& Takahashi, K. (2004). Attachment and close relationships across the life span. Attachment and Human Development, 6(4), 353-370. http://dx.doi.org/10.1080/1461673042000303136

Aucoin, K. J., Frick, P. J., \& Bodin, S. D. (2006). Corporal punishment and child adjustment. Journal of Applied Developmental Psychology, 27, 527-541. http://dx.doi.org/10.1016/j.appdev.2006.08.001

Barnard, M., \& McKeganey, N. (2004). The impact of parental problem drug use on children: What is the problem and what can be done to help? Addiction, 99, 552-559. http://dx.doi.org/10.1111/j.1360-0443.2003.00664.x

Belsky, J. (2005). Differential susceptibility to rearing influence: An evolutionary hypothesis and some evidence. In B. Ellis, \& D. Bjorklund (Eds.), Origins of the social mind: Evolutionary psychology and child development (pp. 139-163). New York: Guilford.

Bohlin, G., Hagekull, B., \& Rydell, A. M. (2000). Attachment and social functioning: A longitudinal study from infancy to middle childhood. Social Development, 9, 24-39. http://dx.doi.org/10.1111/1467-9507.00109

Bonsang, E. (2009). Does informal care from children to their elderly parents substitute for formal care in Europe? Journal of Health Economics, 28(1), 143-154. http://dx.doi.org/10.1016/j.jhealeco.2008.09.002

Booth, A., Johnson, D., Granger, A., Crouter, A., \& McHale, S. (2003). Testosterone and adolescent adjustment: The moderating role of parent-adolescent relationships. Developmental Psychology, 39, 85-98. http://dx.doi.org/10.1037/0012-1649.39.1.85

Booth, A., Granger, D., Mazur, A., Kivlighan, K. (2006). Testosterone and social behavior. Social Forces, 85, 167-191. http://dx.doi.org/10.1353/sof.2006.0116

Bosmans, G., Braet, C., Van Leeuwen, K., \& Beyers, W. (2006). Do parenting behaviors predict externalizing behavior in adolescence, or is attachment the neglected 3rd factor? Journal of Youth and Adolescence, 35, 373-383. http://dx.doi.org/10.1007/s10964-005-9026-1

Boutelle, K., Eisenberg, M. E., Gregory, M. L., \& Neumark-Sztainer, D. (2009). The reciprocal relationship between parent-child connectedness and adolescent emotional functioning over 5 years. Journal of Psychosomatic Research, 66, 309-316. http://dx.doi.org/10.1016/j.jpsychores.2008.10.019

Bowlby, J. (1973). Attachment and loss, volume II. Separation: Anxiety and anger. Procedia Social and Behavioral Sciences, 30, 1625-1629.

Brody, G. H. (1998). Sibling relationship quality: Its Causes and Consequences. Annual Review of Psychology, 49, 1-24. http://dx.doi.org/10.1146/annurev.psych.49.1.1

Brook, J. S., Whiteman, M., \& Zheng, L. (2002). Intergenerational transmission of risks for problem behavior. Journal of Abnormal Child Psychology, 30, 65-76. http://dx.doi.org/10.1023/A:1014283116104

Bugental, D. B. \& Johnston, C. (2000). Parental and Child Cognitions in the Context of the Family. Annual Review of Psychology, 51, 315-344. http://dx.doi.org/10.1146/annurev.psych.51.1.315

Carpenter, B. D. (2001). Attachment bonds between adult daughters and their older mothers: Associations with contemporary caregiving. Journal of Gerontology: Psychological Sciences, 56B(5), 257-266. http://dx.doi.org/10.1093/geronb/56.5.P257

Chacko, J. A., Heiner, J. G., Siu, W., Macy, M., \& Terris, M. K. (2006). Association between marijuana use and transitional cell carcinoma. Urology, 67, 100-104. http://dx.doi.org/10.1016/j.urology.2005.07.005

Crosnoe, R., Mistry, R. S., \& Elder, G. H. (2002). Economic disadvantage, family dynamics, and adolescent enrollment in higher education. Journal of Marriage and Family, 64(3), 690-702. http://dx.doi.org/10.1111/j.1741-3737.2002.00690.x

Day, N. L., Goldschmidt, L., \& Thomas, C. A., (2006). Prenatal marijuana exposure contributes to the prediction 
of marijuana use at age 14. Addiction, 101, 1313-1322. http://dx.doi.org/10.1111/j.1360-0443.2006.01523.x

Difilippo, J. M., \& Overholser, J. C. (2002). Depression, adult attachment and recollections of parental caring during childhood. Journal of Nerves and Mental Disorder, 190, 663-669. http://dx.doi.org/10.1097/00005053-200210000-00002

Dorius, C., Booth, A., Hibel, J., Granger, D. A., \& Johnson, D. (2011). Parents' testosterone and children's perception of parent-child relationship quality. Hormones and Behavior, 60, 512-519. http://dx.doi.org/10.1016/j.yhbeh.2011.07.020

Dunn, J., Davies, L. C., O'Connor, T. G., \& Sturgess, W. (2000). Parents' and partners' life course and family experiences: links with parent-child relationships in different family settings. Journal of Child Psychology and Psychiatry, 41, 995-968. http://dx.doi.org/10.1111/1469-7610.00684

Dykstra, P. A., \& Fokkema, T. (2011). Relationships between parents and their adult children: A West European typology of late-life families. Ageing and Society, 31(4), 545-569. http://dx.doi.org/10.1017/S0144686X10001108

Feldman, R., Guttfreund, D., \& Yerushalmi, H. (1998). Parental care and intrusiveness as predictors of the abilities-achievement gap in adolescence. Journal of Child Psychology and Psychiatry, 39, 721-730. http://dx.doi.org/10.1017/S0021963098002467

Field, A. P., Ball, J. E., Kawycz, N. J., \& Harriett, M. (2007). Parent-Child Relationships and the Verbal Information Pathway to Fear in Children: Two Preliminary Experiments. Behavioural and Cognitive Psychotherapy, 35, 473-486. http://dx.doi.org/10.1017/S1352465807003736

Fingerman, K. L., \& Birditt, K. S. (2011). Relationships between Adults and their Aging parents. Handbook of the Psychology of Aging, 7, 219-232. http://dx.doi.org/10.1016/B978-0-12-380882-0.00014-0

Fincham, F. D., Beach, S. H., Arias, I., \& Brody, G. H. (1998). Children's attributions in the family: The Children's Relationship Attribution Measure. Journal of Family Psychology, 12, 481-493. http://dx.doi.org/10.1037/0893-3200.12.4.481

Fletcher, A. C., Steinberg, L., \& Williams-Wheeler, M. (2004). Parental influences on adolescent problem behavior. Child Development, 75, 781-796. http://dx.doi.org/10.1111/j.1467-8624.2004.00706.x

Galen, B. R., \& Underwood, M. K. (1997). A developmental investigation of social aggression among children. Developmental Psychology, 33, 589-600. http://dx.doi.org/10.1037/0012-1649.33.4.589

Geuzaine, C., Debry, M., \& Liesens, V. (2000). Separation from parents in late adolescence: The same for boys and girls? Journal of Youth and Adolescence, 29, 79-91. http://dx.doi.org/10.1023/A:1005173205791

Glasgow, K. L., Dornbusch, S. M., Troyer, L., Steinberg, L., \& Ritter, P. L. (1997). Parenting styles, adolescents' attributions, and educational outcomes in nine heterogeneous high schools. Child Development, 68, 507-529. http://dx.doi.org/10.2307/1131675

Golombok, S., Jadva, V., Lycett, E., Murray, C., \& MacCallum, F. (2005). Families created by gamete donation: Follow-up at age 2. Human Reproduction, 20, 286-293. http://dx.doi.org/10.1093/humrep/deh585

Golombok, S., Murray, C., Jadva, V., Lycett, E., MacCallum, F., \& Rust, J. (2006). Non-genetic and gestational parenthood: consequences for parent-child relationships and the psychological well-being of mothers, fathers and children at age 3. Human Reproduction, 21(7), 1918-1924. http://dx.doi.org/10.1093/humrep/del039

Griffin, K. W., Botvin, G. J., Scheier, L. M., Diaz, T. L., \& Miller, N. L. (2000). Parenting practices as predictors of substance use, delinquency, and aggression among urban minority youth: moderating effects of family structure and gender. Psychology of Addictive Behaviors, 14, 174-184. http://dx.doi.org/10.1037/0893-164X.14.2.174

Grundy, E., \& Henretta, J. C. (2006). Between elderly parents and adult children: A new look at the intergenerational care provided by the sandwich generation. Ageing \& Society, 26(5), 707-722. http://dx.doi.org/10.1017/S0144686X06004934

Grusec, J. E. (2011). Socialization Processes in the Family: Social and Emotional Development. Annual Review of Psychology, 62, 243-269. http://dx.doi.org/10.1146/annurev.psych.121208.131650

Haberkern, K., \& Szydlik, M. (2010). State care provision, societal opinion and children's care of older parents in 11 European countries. Ageing \& Society, 30(2), 299-323. 
http://dx.doi.org/10.1017/S0144686X09990316

Habib, R. R., Hamdan, M., Al-Sahab, B., Tamim, H., Mack, A., \& Rema, A. A. (2010). The influence of parent-child relationship on safety belt use among school children in Beirut. Health Promotion International, 25(4), 403-411. http://dx.doi.org/10.1093/heapro/daq038

Hetherington, E. M., \& Stanley-Hagan, M. M. (2002). Parenting in divorced and remarried families. Handbook of Parenting, 3, 287-315.

Hoff, A. (2007). Patterns of intergenerational support in grandparent-grandchild and parent child relationships in Germany. Ageing and society, 27(5), 643-665. http://dx.doi.org/10.1017/S0144686X07006095

Kochanska, G., Aksan, N., \& Joy, M. E. (2007). Children's fearfulness as a moderator of parenting in early socialization: Two longitudinal studies. Developmental Psychology, 43, 222-237. http://dx.doi.org/10.1037/0012-1649.43.1.222

Lai, K. W., \& McBride-Chang, C. (2001). Suicidal ideation, parenting style, and family climate among Hong Kong adolescents. International Journal of Psychology, 36(2), 81-87. http://dx.doi.org/10.1080/00207590042000065

Laird, R. D., Pettit, G. S., Bates, J. E., \& Dodge, K. A. (2003). Parents' monitoring-relevant knowledge and adolescents' delinquent behavior: evidence of correlated developmental changes and reciprocal influences. Child Development, 74, 752-768. http://dx.doi.org/10.1111/1467-8624.00566

Lau, A. S., Valeri, S. M., McCarty, C. A., \& Weisz, J. R. (2006). Abusive parents' reports of child behavior problems: Relationship to observed parent-child interactions. Child Abuse \& Neglect, 30, 639-655. http://dx.doi.org/10.1016/j.chiabu.2005.11.009

Ledoux, S., Miller, P., Choquet, M., \& Plant, M. (2002). Family structure, parent-child relationships, and alcohol and other drug use among teenagers in France and the United Kingdom. Alcohol and Alcoholism, 37, 52-60. http://dx.doi.org/10.1093/alcalc/37.1.52

Lemery, K. S., Essex, M. J., \& Smider, N. A. (2002). Revealing the relation between temperament and behavior problem symptoms by eliminating measurement confounding: expert ratings and factor analyses. Child Development, 73(3), 867-882. http://dx.doi.org/10.1111/1467-8624.00444

Lowenstein, A., Katz, R., \& Gur-Yaish, N. (2007). Reciprocity in parent-child exchange and life satisfaction among the elderly: a cross-national perspective. Journal of Social Issues, 63(4), 865-883. http://dx.doi.org/10.1111/j.1540-4560.2007.00541.x

Lye, D. N. (1996). Adult child-parent relationships. Annual Review of Sociology, 22, 79-102. http://dx.doi.org/10.1146/annurev.soc.22.1.79

Maccoby, E. E. (2000). Parenting and its effects on children: On Reading and misreading behavior genetics. Annual review of psychology, 51, 1-27. http://dx.doi.org/10.1146/annurev.psych.51.1.1

Ngai, S. S., Cheung, C., To, S., Liu, Y., \& Song, H. (2013). Parent-child relationships, friendship networks, and developmental outcomes of economically disadvantaged youth in Hong Kong. Children and Youth Services Review, 35, 91-101. http://dx.doi.org/10.1016/j.childyouth.2012.09.025

Ngai, S. Y., \& Cheung, C. K. (2009). The effects of parental care and parental control on the internal assets of adolescent children in Hong Kong. International Journal of Adolescence and Youth, 15, 235-255. http://dx.doi.org/10.1080/02673843.2009.9748031

Nigg, J. T., \& Hinshaw, S. P. (1998). Parent personality traits and psychopathology associated with antisocial behaviors in childhood attention-deficit hyperactivity disorder. Journal of Child Psychology and Psychiatry, 39(2), 145-159. http://dx.doi.org/10.1017/S0021963097001984

Olson, S. L., Bates, J. E., Sandy, J. M., \& Lanthier, R. (2000). Early developmental precursors of externalizing behavior in middle childhood and adolescence. Journal of Abnormal Child Psychology, 28(2), 119-133. http://dx.doi.org/10.1023/A:1005166629744

Orlov, A. (1996). The evolution of interpersonal relations in the family: The main approaches, orientations and trends. Magister, 1, 52-64.

Orthner, D. K., Jones-Sanpei, H., \& Williamson, S. (2004). The resilience and strengths of low-income families. Family Relations, 53(2), 159-167. http://dx.doi.org/10.1111/j.0022-2445.2004.00006.x

Patock-Peckham, J. A., Cheong, J., Balhorn, M. E., \& Nagoshi, C. T. (2001). A social learning perspective: A 
model of parenting styles, self-regulation, perceived drinking control, and alcohol use problems. Alcoholism: Clinical and Experimental Research, 25, 1284-1292. http://dx.doi.org/10.1111/j.1530-0277.2001.tb02349.x

Patricia-Luciana, R. (2011). The time factor: Does it influence the parent-child relationship?! Elsevier, Procedia-Social and Behavioral Sciences, 33, 11-14.

Phillips, D. A., \& Lowenstein, A. E. (2011). Early Care, Education, and Child Development. Annual Review of Psychology, 62, 483-500. http://dx.doi.org/10.1146/annurev.psych.031809.130707

Rettew, D. C., Stanger, C., McKee, L., Doyle, A., \& Hudziak, J. J. (2010). Interactions Between Child and Parent Temperament and Child Behavior Problems. Focus, 8, 276-285. http://dx.doi.org/10.1176/foc.8.2.foc276

Riggs, N. R., Chou, C. P., \& Pentz, M. A. (2009). Protecting against intergenerational problem behavior: Mediational effects of prevented marijuana use on second-generation parent-child relationships and child impulsivity. Drug and Alcohol Dependence, 100, 153-160. http://dx.doi.org/10.1016/j.drugalcdep.2008.10.003

Schmeck, K., \& Poustka, F. (2001). Temperament and disruptive behavior disorders. Psychopathology, 34(3), 159-163. http://dx.doi.org/10.1159/000049300

Shiner, R., \& Caspi, A. (2003). Personality differences in childhood and adolescence: Measurement, development, and consequences. Journal of Child Psychology \& Psychiatry, 44(1), 2-32. http://dx.doi.org/10.1111/1469-7610.00101

Smart, R. G., \& Ogborne, A. C. (2000). Drug use and drinking among students in 36 countries. Addictive Behaviors, 25, 455-460. http://dx.doi.org/10.1016/S0306-4603(99)00013-1

Stewart-Brown, S. L., Fletcher, L. W., \& Michael, E. J. (2005). Parent-child relationships and health problems in adulthood in three UK national birth cohort studies. European Journal of Public Health, 15(6), 640-646. http://dx.doi.org/10.1093/eurpub/cki049

Swiss, L., \& Le Bourdais, C. (2009). Father-child contact after separation The influence of living arrangements. Journal of Family Issues, 30, 623-652. http://dx.doi.org/10.1177/0192513X08331023

Szinovacz, M. E., \& Davey, A. (2013). Changes in adult children's participation in parent care. Ageing and society, 33(4), 667-697. http://dx.doi.org/10.1017/S0144686X12000177

Teresa, T. S. (2009). Intergenerational Family Relations in Adulthood: Patterns, Variations, and Implications in the Contemporary United States. Annual Review of Sociology, 35, 191-212. $\mathrm{http}: / / \mathrm{dx}$. doi.org/10.1146/annurev.soc.34.040507.134615

Troll, L. E., \& Fingerman, K. L. (1996). Connections between parents and their adult children. In C. Magai, \& S. McFadden (Eds.), Handbook of emotion, adult development, and aging (pp. 185-205). San Diego: Academic Press. http://dx.doi.org/10.1016/B978-012464995-8/50012-1

Varga, A. (2011). Introduction into the family systems therapy (p. 2). Moscow: Cogito.

Windle, M. (2000). Parent, sibling, and peer influences on adolescent substance use and alcohol problems. Applied Developmental Science, 4, 98-110. http://dx.doi.org/10.1207/S1532480XADS0402_5

\section{Copyrights}

Copyright for this article is retained by the author(s), with first publication rights granted to the journal. This is an open-access article distributed under the terms and conditions of the Creative Commons Attribution license (http://creativecommons.org/licenses/by/3.0/). 